\title{
Transnational mercantilism and the emergent global trading order Jean-Christophe Graz
}

\begin{abstract}
It is often argued that the problems currently facing the World Trade Organization stem from an important shift in the trade agenda from tariff reduction to the harmonisation of domestic regulations considered as non tariff barriers. From this perspective, the lack of harmonisation of domestic regulations severely impairs the capacity of the WTO to fulfil its mission. This article argues, in contrast, that the underlying problems facing the contemporary trade agenda are different, and are caused by a lack of differentiation in the regulatory framework of the WTO. To substantiate this claim, a conception of transnational mercantilism is derived from recent scholarly revisions of classical mercantilism. This clarifies a continuity between the external dimension and the comprehensive pattern of social organisation involved in the political economy of international trade. This framework is used to appraise four structures upon which trade policy is predicated: the implementation of market mechanisms, the embeddedness of trade in state-society relations, the link between trade and the natural environment, and special and differential treatment for developing countries.
\end{abstract}

\section{KEYWORDS}

World Trade Organisation; new trade agenda; Doha development agenda; international political economy; transnational mercantilism.

\section{INTRODUCTION}

It is often argued that a 'new trade agenda' has emerged in the past few years. This new trade agenda has shifted from trade liberalisation based on tariff concessions (a so-called 'shallow integration') to 'deep integration', or harmonisation of domestic regulations deemed to have an impact on trade. ${ }^{1}$ The article explores the increasingly controversial status of a global trading order which brings new areas of public life within the ambit of the World Trade Organization (WTO). Since its inception, the WTO has appropriated a wide variety of new trade-related issues, including

Review of International Political Economy

ISSN 0969-2290 print/ISSN 1466-4526 online (C) 2004 Taylor \& Francis Ltd

http:/ / www.tandf.co.uk

DOI: $10.1080 / 0969229042000252918$ 


\section{REVIEW OF INTERNATIONAL POLITICAL ECONOMY}

intellectual property, investment policy, health and safety regulations, and industrial standards. Issues such as competition policy, government procurements and environmental regulation are in the pipeline. These in turn, have prompted protests from a growing array of transnational social movements. Both liberals and critics of the new trade agenda interpreted the failure of the 1999 WTO Ministerial conference in Seattle to launch a new round of negotiations as evidence of the difficulties of encroaching upon crucial domestic policy areas (Dymond and Hart, 2000; Gill, 2000). The new round of trade negotiations agreed to by the Doha Ministerial conference in November 2001, the so-called 'Doha Development Agenda' (WTO, 2001a), failed to overcome this controversy. Indeed, according to Pascal Lamy (2001), the European Trade Commissioner, Doha 'should contribute crucially to improved governance by expanding considerably the areas of trade-related matters subject to global rules'. Critics argue, however, that without the 'convergences required to replace the WTO's bid for a corporate utopia with an international citizen's agenda that protects the poor and the planet [...] Doha will be known as a pivotal point in history where global governance was truly usurped' (Menotti, 2002: 2).

Advocates of the new trade agenda have tended to assume that broadening the scope of trade policy issues to include harmonisation of domestic regulations requires the penetration of market mechanisms into more and more areas of social life. Lately, the perspective has been amended in pragmatic as well as legal terms (e.g. Alvarez, 2002; Dymond and Hart, 2000; Marceau and Trachman, 2002). The route taken by the current revision echoes the discourse on 'globalisation with a human face'; but as borne out by the recent difficulties of the WTO, there is a lack of clear principles and criteria to define ways in which a wider array of domestic policy issues can have a substantial and disparate impact on international trade. Thus, the revision fails to explore how the social dimension of the new trade agenda would limit a fully-fledged harmonisation of the global trading order. It fails to grasp the unquantifiable and mutually incompatible issues that fall within the scope of the new trade agenda. In other words, it is not the shift towards deep integration in itself, and the lack of principles guiding this shift that explain the recent difficulties faced by the WTO, but rather the content of deep integration and its guiding principles.

The claim of this paper is that the current difficulties of the WTO reflect a lack of consensus on the level of differentiation in trade policy required for a comprehensive global trading order. The argument draws upon the recent scholarly revision of classical mercantilism. ${ }^{2}$ This body of literature provides new means to conceptualise the selective and differentiated role of the state in trade policy. The value in use of the goods to be exchanged was a key criterion in the concerns of mercantilist authors for a positive balance of trade. To translate into the contemporary debate the lessons that 
can be drawn from authors who wrote centuries ago, I introduce the concept of transnational mercantilism. At first sight this might appear to be an oxymoron. However, identifying mercantilism as transnational brings out a tension which exists when state practices in the area of non-market issues are put to the test by those involved in the transnational drive of capitalism. Following heterodox traditions in global political economy, the concept of transnational mercantilism privileges socio-historical over structural explanations of the political economy of global trade. ${ }^{3}$ Such an understanding gives substance to the contemporary debate on the rationale for a socially defined appraisal of trade policy in a capitalist environment. It also gives additional purchase to the understanding of a global trading order as one undermined by the claims of subordinate social interests, as opposed to an explanation which relies merely on the lack of American leadership, or the assumed threats of unilateralism and regionalism.

The argument is organised as follows. The first part develops a theoretical framework that specifies the controversial nature of the WTO in a comprehensively defined global trading order. It posits the largely misunderstood relevance of classical mercantilist authors to generate a critical analysis of the new trade agenda. The second part examines four areas of controversy for a comprehensive, yet differentiated trade agenda. It analyses significant limits to the transnationalisation of the global trading order. It is divided into four sections: the implementation of market mechanisms (freer non-discriminatory trade); the embeddedness of trade into state-society relations (e.g. employment, labour standards, public utilities); into nature (e.g. trade in primary commodities, agriculture, environmental concerns); and into the spatio-temporal structure of capitalism (e.g. special and differential treatment for development concerns). The conclusion summarises the argument and projects implications for future research.

\section{THE POLITICAL ECONOMY OF TRANSNATIONAL MERCANTILISM}

Both pragmatic and legal analyses have recently undermined the assumption that the major problems of the WTO rest on the weaknesses of a rulebased market harmonisation. In the aftermath of the 'Battle of Seattle', trade practitioners have become more inclined to endorse the idea that the new trade agenda can encompass differences in economic regulation having little to do with the need for rent-seeking protection against imports. According to Dymond and Hart (2000: 30), 'while there may be a solid economic case for liberalisation through national treatment principles reinforced by harmonisation, the effect is to bring into question the deep social and historical roots which underpin systems of national or sub-national regulation and thus raise profound issues of national self-determination'. While the Doha agenda embodies potential flexibility 
on a range of issues, the following meeting in Cancun, 2003, notoriously failed to give substance to it.

Legal scholars have criticised the most libertarian version of a 'constitutional' argument in defence of an extended market-based trade agenda. This view calls for a broader scope of the GATT/WTO legal order, seeing it as rooted in classical constitutional law establishing property and contractual rights as core natural rights, and therefore contributing to limit state capacities to enhance the economic freedom of individuals (Petersmann, 1991, 2003). Howse (2002: 105) highlights the implications of this line of argument: 'If free trade is recast in terms of [constitutional] rights, it must obviously be integrated or balanced somehow with other human rights'. There is indeed no reason why the trading system itself should have the legitimacy to strike the balance. Other institutions more closely related to positive constitutional rights, such as the United Nations organs in charge of international human rights law or the domestic institutions of liberal democracies, could claim the same role. According to Cottier (2002: 127), trade and nontrade considerations are mutually compatible in the pursuit of fuller coherence between the multilateral trading system and human rights. In contrast, Howse (2002: 105) concludes that 'a line of argument that seeks to prevent the collapse of the trading system into politics really ends up collapsing it into the complexly, but unmistakably political realm of human rights discourse'. Some critical legal scholars have now provided legal tools for mediating the tensions between developed and developing countries and the relationship between domestic institutions and the goals of the trading system (Howse and Nicolaidis, 2001: Picciotto, 2003). They do not explore, however, the political economy that underpins the coexistence of free trade and protectionism in the attempt to harmonise the global trading order on a comprehensive basis.

On historical grounds there is nothing new in the assumption that protection and freedom of trade may coexist. Protectionism has mainly posited temporal and sectoral limits amending the claim of free trade to be a general and transhistorical principle. In many respects, this perspective is merely a continuation of the classical mercantilist literature of the late seventeenth and early eighteenth centuries (Bairoch, 2001; Heilperin, 1963; Margerum Harlen, 1999; Morini-Comby, 1930; Siroën, 1992). Ever since Adam Smith, conventional wisdom had been that mercantilism confused wealth with money. However, mercantilist theories of the balance of trade abandoned a definition of the value of exchange based on specie only since the late seventeenth century. Not only did they relate monetary and commercial issues, but also those of production and consumption. ${ }^{4}$ Neither was mercantilism a doctrine directed towards the restraint of imports and promotion of exports solely in favour of the interests of chartered companies. As early as the seventeenth century their monopolistic behaviour in trade prompted fierce debate. A pamphlet of 1645 against the British Merchant Adventurers 
claimed for instance that 'Trade is like Dung, which being closed kept in a heap or two stinks, but being spread abroad it doth fertilise the earth and make it more fructable' (quoted in Magnusson, 1993: 102).

Perrotta (1988: ch. 4, 5, 7; 1991, 1997) offers a powerful explanation of the peculiar juncture between freedom and protection of trade perceived by most mercantilist authors. The theory of the positive balance of trade is not a mere dyad between the control of markets overseas and protection of the domestic market. The quest for a surplus balance of trade is grounded in the value in use of the goods traded, not in specie or only exchange value. Perrotta's interpretation is founded upon the distinction that William Petty made in the seventeenth century between productive and unproductive labour: the definition of productive labour, to become a new standard of value, partly hinges upon its capacity to create value beneficial to society, i.e. use value. This implies that the criterion guiding state intervention in the pursuit of a trade surplus is the productive potential considered socially useful. At the beginning of industrial capitalism, this was realised through restraints on the import of luxury goods, so as to encourage investment in the education of skilled labour, access to cheap primary goods, to support the growth of manufactures, and the export of manufactured goods.

The concept of transnational mercantilism seeks to apply the insights of classical mercantilism to grasp a tension at the core of the new trade agenda. It describes a situation where states hold themselves accountable for any latent, possible, or effective impact of domestic regulations on the trading system. It clarifies why the relationship between the transnationalisation of capitalism and the economic and social role of political authority remains problematic in matters of trade. The classical doctrine of the positive balance of trade was never only about trade. It pertained to the use of a balance in fostering a particular type of society. Likewise, the concept of transnational mercantilism takes into account the social value attributed to the effect of trade, and consequently enables the critical investigation of trade regulation in its impact upon society as a whole. It is from this perspective that the balance between market rules and state intervention in trade regulation is a matter of ongoing social and political debates, ultimately affecting the very legitimacy of states. Such an understanding of transnational mercantilism provides a way to conceptualise the political economy of global trade in parallel with three major claims of the heterodox tradition of global political economy: the differentiation between the political and economic spheres, the functional articulation between domestic and global realms, and the embeddedness of the economy in broader concerns of society and civilisation.

First, in line with the argument of social theorists such as Braudel, Polanyi, Gramsci and others, the concept of transnational mercantilism highlights the contested role of political authority in the organisation of material life. This central feature of capitalism and modern forms of state 


\section{REVIEW OF INTERNATIONAL POLITICAL ECONOMY}

entails a differentiation between a sphere of economic activities governed by market constraints and that of political action directed to the general interest of society on a defined territorial space. Despite major theoretical and analytical disagreements, heterodox approaches on the conflictual articulation of the political and economic spheres share a critical posture which has led Cox (2002: 79) to point out that the real achievement of IPE was not to bring in economics, but to open up a critical investigation into change in historical structures'. It is by assuming the reflective and transformative aspect of knowledge and consciousness that a critical standpoint appraises the defining boundary between the social relations involved in the economic and political spheres as an object of contestation. As Rupert (1995: 40) argues, the concrete shape of the relations between the economic and political spheres is not given, but 'socially produced and historically mutable'.

Second, the concept of transnational mercantilism takes into account the intimate connection between domestic and global realms. In the wake of Marx's 'the world market is the bedrock of capitalism', Braudel argued 'the modern state will have been one reality among many others in which capitalism has made its way, sometimes hindered, sometimes favoured. [But] capitalism has always worn giants' boots' (Braudel, 1979: vol. 2, p. 494; Marx, 1968: Book II, section 4, ch. XIII, p. 1101). As political mediations are inherent in the economy, they inevitably have an impact on international exchanges when a significant portion of the exchanged of goods and services crosses borders. This impact takes contingent forms, which should be assessed according to the historicity of struggles influencing the selective and differentiated interventions of the state. In this sense, by calling attention to the pervading relations between domestic and trade politics, the concept of transnational mercantilism tackles from a specific perspective what Palan describes as the central focus of heterodox IPE studies: 'discontinuity between political and economic spaces is one of the major sources of continuing change in international political economy'(1998: 68).

Finally, transnational mercantilism allows a broadening of the object of trade policy. By placing on equal footing the quantifiable aspect of productive labour (exchange value) and its non-quantifiable standard of social utility (use value), classical mercantilism emphasised the societal dimension of selective and differentiated intervention of the state. This explains the futility of trade-offs between free-trade and protectionism when the new trade agenda deals with the harmonisation domestic regulations. Moreover, it provides a way to develop a framework of understanding beyond the nexus of free-trade and protectionism, thus abolishing the conventional distinction between commercial policy and political economy.

The argument presented here reflects increasing doubts as to the worldwide consequences of neoliberal globalisation, as they become apparent in the controversies over the differentiation of a comprehensive trading order 
on a world-wide scale. The concept of transnational mercantilism provides a specific explanation why commercial regulation rests on two interrelated criteria: the comprehensiveness of commitments relating to a wide range of economic and social functions of the state, and the differentiation to be established between market and non-market provisions. The remainder of this article uses this framework to evaluate attempts to further harmonise the global trading order.

\section{DEFINING A COMPREHENSIVE AND DIFFERENTIATED GLOBAL TRADING ORDER}

The purpose here is to put the current debate on the WTO into the perspective of the comprehensive and differentiated concept of trade as developed in the preceding theoretical section. This goes beyond an analysis of the consequences of the Uruguay Round or a study of the WTO as an international organisation (Jackson, 2000; Krueger, 1998; Trebilcock and Howse, 1999; Wilkinson, 2000). Rather, I try to assess the extent to which the new round of negotiations launched at Doha on November 14, 2001, addresses the deep concerns shared by numerous actors concerning the legitimacy of the WTO in the aftermath of the 'Battle of Seattle'.$^{5}$ This requires a more detailed examination of how the WTO frames trade policies predicated not only upon the implementation of market mechanisms, but also on the comprehensive scope of the varying embeddedness of trade into the state-society complex, its relation to nature, and special and differential treatment for developing countries. Among the delegations to the current negotiations of the so-called Doha Development Agenda, few would disagree with these broad goals. However, many disagree on the proper balance to strike within this comprehensive agenda.

\section{Market implementation}

The key question regarding the implementation of market mechanisms in the multilateral trading system is the extent to which reducing discriminatory trade barriers should be reduced. There are four fundamental principles in support of a freer and non-discriminatory international trade policy. The first is a commitment to enter into negotiations upon request to carry out this general purpose. The second is a pledge towards the elimination of quotas, which distort the operations of the price mechanism in a market economy. The third is the unconditional 'most-favoured-nation' clause, which calls for each member of a commercial treaty to grant one another the most favourable treatment which they grant to any other trading partner. Finally, the fourth and corollary obligation is 'national treatment', which deals with the non-discriminatory treatment of imported goods once they have cleared customs. 
All these clauses prevail in the legal framework of the WTO and they have been implemented on a substantial scale during the GATT history. As compared to 40 percent in the post-war era, average tariff on industrial goods among industrial countries now stands at 4 percent, and more than 40 percent of those goods are granted duty-free entry. Tariff bindings cover not only industrial goods among industrial countries, but also all agricultural goods and tariffs applied more and more in developing and 'transition' economies. A great number of non-tariff restrictions have been prohibited as well. Moreover, contrary to the results obtained after the Tokyo Round, all members of the WTO are committed to the different agreements attached to the results of the Uruguay Round. Finally, gradual integration of developing countries toward MFN treatment is assured by the Uruguay Round provisions. The traditional avenues of protectionist policies still include, however, many hot issues, such as the 2002 American decision to raise by 30 percent tariffs on steel imports or the long-standing arrangements protecting the textile and clothing industries of the industrialised countries.

As we have seen in the preceding section, deterritorialising the marketincentive and socially protective functions of the state is a key feature of transnational mercantilism. Hence, even if trade liberalisation proceeded further, an economic policy cast so that the transnationalisation of the economy is presented as beneficial to all nationals still implies the involvement of the state. The differentiated conditions of exchange stemming from such measures stand at the core of controversies in domains such as export subsidies, dumping, intellectual property, investment and competition, and technical barriers to trade. Besides various disputes under review in the Dispute Settlement Body of the WTO, the case of intellectual property is probably the most contested issue linking market-incentive functions of the state to the differentiated embeddedness of markets in the global trading order.

The agreement on 'trade-related aspects of intellectual property rights' (TRIPs) adds to the WTO agenda one of the key issues related to what the post-World War II planners were concerned about when dealing with 'restrictive business practices'(Graz, 1999: 188-93). Private control over patents was one of the main rationales for cartel arrangements in the inter-war years. It is now one among numerous channels used by transnational corporations to distort competition by restraining the diffusion of knowledge and technology. In contrast with the conventions negotiated under the World Intellectual Property Organization (WIPO), the TRIPs agreement marks a breakthrough by requiring states to provide civil and criminal procedures for the enforcement of intellectual property rights. Since it mainly benefits 'those who own both the knowledge being coded as property and the technology to exploit it' (May, 1998: 75), this agreement ties in only too well with state incentive functions related to the 
transnationalisation of capitalism. A sample case is provided by TRIPs article 27.3c that excludes patents on micro-organisms from the ban of patents on life. The biggest multinational corporations in biotechnology and pharmaceutical products are the key beneficiaries of such protection of property rights by states. They played an important proactive role in pushing the agenda into the Uruguay Round (Sell, 1999). In 2001, the outrage that followed the failed AIDS lawsuit by 40 pharmaceutical firms against the government of South Africa has brought back to the forefront the threat to biodiversity and healthcare systems in the case of a full implementation of the agreement (Wall Street Journal, 2001; World Trade Organization, 2001b). States like Brazil, India and South Africa, whose industries can produce generics under compulsory licensing, are backed by those without such facilities to redress the balance of proprietary rights in favour of public health concerns. It remains unclear, however, how far the 2003 decision of the WTO on the implementation of paragraph 6 of the Doha 'Declaration on the TRIPs Agreement and Public Health' will provide a more balanced interpretation of the relationship between private intellectual property and public health policy. Yet, while only 5 percent of the nearly six million people with AIDS in the developing world have access to antiretroviral treatment, the proper use of compulsory licensing for domestic and third party concerns remains a matter of harsh debate (Piot, 2003).

\section{The embeddedness of trade in the state-society complex}

The institutional framework of the WTO lies beyond a narrow definition of a world market of goods and services. In many ways it deals with a situation where states are accountable for the impact on the international trading system of social relations engendered by the articulation between the economic and political spheres. References to 'raising standards of living' and 'full employment' are made in the very first paragraph of the WTO preamble. However, instead of exceptions for effective interventions related to such states' socio-economic functions, the Uruguay Round did not give much license to differentiated means to provide social protection. The issue of employment and welfare has now come back to the forefront of the WTO agenda. The impact that state-society relations have on trade with regard to labour standards and services are among the most hotly debated issues.

The debate over core labour standards refers to the social guarantees given to labour as stipulated in seven ILO Conventions (29, 87, 98, 105, $100,111,138)$. These fundamental rights provide for freedom of association and collective bargaining, prohibition of forced labour, prevention of discrimination in employment, and a minimum age for employment. Whereas organised labour and grass root organisations tied closely to 


\section{REVIEW OF INTERNATIONAL POLITICAL ECONOMY}

most employer organisations and governments in rich countries to integrate core labour standards into the WTO, in poor countries a number of independent labour unions shared government's views and corporate interests in their strong hostility to any linkage between labour standards and trade concerns. Labour standards were ruled out of the WTO agenda at the 1996 Singapore meeting. Not only did the Final Declaration state that the ILO was to be the sole 'competent body to set and deal with these standards', it furthermore set aside the potential use of trade restrictions for their promotion by reaffirming that 'economic growth and development fostered by increased trade and further trade liberalisation contribute to the promotion of these standards'. Despite the new 'integrated' approach of the ILO to enhance its standards-related activities, the firewall set between the two bodies has remained highly controversial. ${ }^{6}$ The SafeWork programme started in 1998-99, whose objective is to prepare ILO Guidelines in the area of occupational health and safety (OHS), has much to do with the failure of British Standards Institutions (BSI) to introduce OHS standards within the International Organisation for Standardisation (ISO); this is not anecdotal, since the WTO agreement on Technical Barriers to Trade recognises ISO-like international standards as potentially legitimate measures notwithstanding their impact on trade. ${ }^{7}$ In the near future, issues such as social labelling and the proposed ISO Corporate Responsibility Management System Standard may well rekindle the controversy. ${ }^{8}$

The disputed nature of trade in services has also gained momentum since it has become clear that the scope of current negotiations increasingly overlaps the traditional functions of public utilities. The Preamble of the General Agreement on Trade and Services (GATS) explicitly endorses the differentiated embeddedness of the global market for services within state-society relations: it recognises 'the right of members to regulate, and to introduce new regulations, on the supply of services within their territories [and] the particular need of developing countries to exercise this right'. At the same time the GATS defines a framework for future market-oriented negotiations by locking in 'successive rounds of negotiations [...] with a view to achieving progressively a higher level of liberalisation' (GATS, article XIX). ${ }^{9}$ The means by which the GATS should strike a balance between further trade liberalisation and the regulatory rights of governments are specified in article VI:4 which assigns the Council for Trade and Services the largely market-inspired task to develop 'any necessary discipline' to ensure that domestic regulations 'do not constitute unnecessary barriers to trade [and are] not more burdensome than necessary to ensure the quality of the services'.

After significant steps made in 1997 on telecommunications and financial services, negotiations set in motion in February 2000 directly challenge the flimsy frontier remaining between commercial services and public 
utilities. The request lists submitted to the WTO Secretariat leave out almost no public utilities or modes of supply. Documents prepared by the European Commission reveal its intention to include, beside tourism and transport, essential services such as water and energy. ${ }^{10}$ Prior to the ill-fated Seattle Ministerial meeting in 1999, American demands added such items as global market access to education and health (World Trade Organization, 1999). Following the growing concerns of activists that government policies towards public education and healthcare could be considered as barriers to trade like subsidies or government support, the US requests submitted in 2002 have slightly amended the list by withdrawing areas such as water supply, public health and primary and secondary education. ${ }^{11}$ While a small group of OECD countries are clearly the driving force of negotiations pursuing the agenda of multinational service corporations based in their countries, most LDCs and activists oppose a further expansion of policies aimed at turning public services into private markets. The Doha Declaration establishes that, contrary to the process endorsed in the Uruguay Round, the conclusions of the negotiations on services would be part of a single undertaking. Services will definitely be part of large trade-offs regarding the level of their embeddedness into a market-based environment. ${ }^{12}$

\section{The embeddedness of trade within nature}

The distinct framework necessary for the production and exchange of goods closely embedded in natural constraints has always been a major social concern. Since the conclusion of the Uruguay Round, the differentiated framework for trade regulation in agriculture remains one of the most controversial features of the WTO. Moreover, the issue of nature in its relation to trade is now supplemented by broader environmental concerns.

Regarding agriculture, WTO members have recognised that 'the longterm objective of substantial, progressive reductions in support and protection, resulting in fundamental reform [in world agricultural trade] is an ongoing process' (art. 20 of the Agreement on Agriculture). According to the timeframe set for this part of the WTO agenda, negotiations began in March 2000. Yet one might cast doubt on the capacity to 'establish a fair and market-oriented agricultural trading system' (art. 20.c) without consideration of major social concerns. The Doha Ministerial Declaration has recognised this tension by including mostly European and Japanese claims to incorporate 'non-trade concerns' (WTO, 2000, 2001a, para 13). Today aggregate agricultural support in the OECD countries is equivalent to almost 60 percent of total world agricultural trade, an amount which not only feeds transatlantic tensions, but also deeply challenges developing countries' export markets, endangers the rural livelihoods of local producers, and threatens their food security (UNCTAD, 
1999a). All these concerns were raised when President Bush signed in May 2002 the highly controversial Farm Bill worth $\$ 180$ billions over 10 years which will increase subsidies to American farmers by up to 70 percent. ${ }^{13}$ There is much misunderstanding, however, in the widely held claim that a more market-based agriculture among OECD countries could be a tradeoff for missed export opportunities borne by LDC farmers. An undifferentiated transnationalisation of world markets in agriculture would put half a billion farmers of the South in direct competition with the Northern hemisphere's industrial agro-businesses, where productivity per farmer may be up to 1000 times higher (Bessière, 2001; Mazoyer and Roudart, 2002). Moreover, since the productivist standards in agriculture have now reached the border line of land and human physiological sustainability, current negotiations on the degree to which states should respond to 'nontrade concerns' could eventually mean significant advances on food safety and quality factors, soil preservation, and animal welfare. Thus, although the reform process called for in the current negotiations is strongly biased towards transnationalising agricultural markets, it could hardly ignore the mercantilist claims regarding the use value aspect of agricultural trade, be it for price stability, land preservation, or broader environmental concerns.

Regarding the environment, WTO member states have until recently subordinated the development of explicit measures to the view that the preconditions for sustainable development lie in economic resources and transfers of 'clean' technology facilitated by the freeing of trade and investment. The liberalisation of trade in environmental goods and services adopted in paragraph 31 (iii) of the Doha Declaration follows this line of argument. An increasing number of trade disputes refer, however, to the environment. ${ }^{14}$ More generally, many environmental groups contest on principle the ability of the market to provide a sufficient response to environmental problems. They claim that trade policy is embedded in the biosphere, which is finite and with constraining laws which the global economy has to comply with. The decision-making bodies of the WTO try hard to keep trade and the environment in watertight compartments. But it remains unclear how the loose provisions of GATT art. XX chapeau, $b, g$ and the specific mandate of the Doha Declaration (31(i)) on 'the relationship between WTO rules and specific trade obligations set out in Multilateral Environmental Agreements' will settle this controversial issue. Other WTO provisions refer implicitly to environmental norms. The Agreement on Technical Barriers to Trade (TBT) refers to ISO-like international standards and specifies the use of technical governmental regulations in this domain (art. 2.4). The same exogenous logic prevails in the Agreement on Sanitary and Phytosanitary Measures (SPS) as regard to food standards provided by the joint WHO-FAO Codex Alimentarius (art. 10-12). 
Thus, the WTO has so far declined to endogenise the relationship between trade and the natural environment (Damian and Graz, 2001). Deadlines for defining modalities of negotiation in agriculture have repeatedly been missed. Regarding specific environmental issues, the Doha agenda is limited to further liberalisation of environmental goods and services and to the relationship between the WTO and Multilateral Environmental Agreements. To settle trade disputes even loosely connected with nature, the WTO relies on a range of exogenous institutions and standards. The only jurisdiction of the WTO lies in giving a ruling on whether trade restrictions notified by states are scientifically based and legally consistent with the WTO's own regulatory framework (above all in terms of nondiscrimination and national treatment). Whereas transnational mercantilism refers to the public sphere where states are accountable for the impact of domestic regulations on the trading system, so far the definition of a legitimate or illegitimate differentiation of the global trading order for 'non trade concerns' in agriculture and broader environmental issues is, on the contrary, left in the hands of a very small number of scientists and legal experts.

\section{Space and time}

The differentiated needs of member-states according to their distinctive integration in global capitalism concurred until recently mostly with trade liberalisation: 'open trade' policies are conducive to growth. This conclusion appears to hold regardless of the level of development of the countries concerned' read the 1998 WTO Annual Report (pp.5-6) (see also Ben-David et al., 2000). The carefully chosen words for the new Round of negotiations launched in 2002 - the Doha Development Agenda - is in itself an expression of the shift that has taken place. More specifically, the Ministerial Declaration agreed that 'all special and differential treatment provisions shall be reviewed with a view to strengthening them and making them more precise, effective and operational' (WTO, 2001a: para 44). Moreover, by adopting the Decision on Implementation-Related Issues and Concerns, it instructs the Committee on Trade and Development to consider more broadly 'how special and differential treatment may be incorporated into the architecture of WTO rules' (WTO, 2001c: para 12iii). Continued disagreement on the proper weight to be given to that mandate has impaired the special sessions on special and differential treatment since their creation in February 2002. After several missed deadlines, the credibility of the WTO is now closely related to its capacity to address on a satisfactory basis the spatio-temporal differentiation of global capitalism (Kwa, 2002; Stephens, 2003).

The implementation concerns related to the Uruguay Round Agreement have become crucial for most LDCs. WTO rules remain deeply unbalanced 


\section{REVIEW OF INTERNATIONAL POLITICAL ECONOMY}

in several important development-related areas such as the protection of intellectual property rights, the use of industrial subsidies and anti-dumping measures by developed countries in specific sectors of export interest to LDCs, or the new disciplines imposed on the use of certain trade-related investment measures (OXFAM, 2002). Agricultural exports from developing countries remain greatly hampered by massive domestic support and export subsidies in developed countries, whereas the discipline imposed on developing countries raises increasing concerns. Whereas the Agreement on Textiles and Clothing was heralded as a major achievement for the LDCs in committing the developed countries to lift all quotas on imports and other discriminatory instruments of the Multifiber Agreement (MFA) by January 1, 2005, the difficulties encountered in the implementation process have now led to the widely held belief that, while the MFA may disappear, it may well be replaced by a series of other trade instruments, and possibly substantial increases in anti-dumping duties. In the field of services, the breakthrough made in GATS by including the movement of natural persons as one of the four modes of supply in exchanging services also remains lopsided; LDCs have little chance to include in this item workers other than those active in professional services provided by the big multinational accountancy firms, consultant groups, insurance or financial companies.

In terms of market access, even with a full implementation of the Uruguay Round, the average tariff on imports from LDCs would still be 10 percent higher than the average tariff on imports from other developed countries. It is the sectors specifically involved in the path of technological upgrading and structural transformation of developing economies that face the highest average tariffs, tariff peaks, tariff escalation and non-tariff barriers when exported to northern markets (UNCTAD, 1999b: 134-46). According to Rubens Ricupero, Secretary-General of UNCTAD, this 'provides sufficient grounds to retain the infant-industry concept as an integral part of trade policy discussion' (UNCTAD, 1999b: x).

The distributional issue related to free trade is the reason why the transnational drive embodied by the WTO framework raises concerns for the vast majority of the world's population. Besides the implementation of the Uruguay Round, market reforms forced upon developing countries in the aftermath of the first debt crisis and the succession of financial crises that have plagued the 1990s have led towards increasing distrust. This, in turn, has prompted more organised struggles against policies pursuing the transnationalisation of the economy. The victories of leftwing presidents in Brazil and Equador in 2002 and the resistance to destabilisation in Venezuela are sometimes portrayed as a Latin American model for weakening neoliberal hegemony across the developing world (Ramonet, 2003). It is within this broader picture that the ongoing negotiations on the extent of 'special and differential treatment' reflect the difficulty for the WTO 
to face the demands for a better differentiated regulatory framework in which the space and time constraints of global capitalism are duly taken into consideration.

\section{CONCLUSIONS}

This article has explored the problems encountered by the WTO in the shift from a trade agenda focused on tariff reduction to the harmonisation of domestic regulations in consequence of their impact on international exchanges. It suggests that the WTO, as the core forum of the global trading order, is now facing a fundamental crisis because of its failure to strike an acceptable balance between market and non-market provisions on a comprehensive scope and world-wide basis. Although the mandate of the so-called 'Doha Development Agenda' includes provisions giving a more balanced interpretation of the embeddedness of international trade in nontrade concerns, it remains unclear whether this slight revision should be seen as anything more than a pragmatic response to the tensions between developed and developing countries, and growing domestic concerns regarding the goals of the multilateral trading system. A number of implications arise from this analysis.

First, the theoretical framework contrasts with the conventional analyses of the so-called 'new trade agenda'. Most scholars are concerned with the harmonisation of an ever-increasing range of domestic policies considered to have an impact on trade and the compatibility of these policies with major non-trade concerns such as human rights or the environment. This paper has focused, on the contrary, on the contradictory nature of the global trading order and this impacts on the WTO. The concept of transnational mercantilism makes explicit the problematic relationship between the transnationalisation of capitalism and the economic and social roles of political authorities within a defined space. It is clear that within classical mercantilist thinking the mediations shaping the specific configurations between the economic and political realms of trade policy remain elusive. Put bluntly, Marx may have been wrong in accusing mercantilists of succumbing to the fetishism of commodities, since use value was one of their key concerns; he was right, however, to consider that the criteria for determining use value did not take into account the social relations of production in a capitalist environment. ${ }^{15}$ Yet, mercantilist thinking allows us to reconceptualise the politics of trade by reference to three major claims: the articulation between the economic and political spheres, the intimate connection between domestic and international realms, and the embeddedness of trade policy within broader political economy concerns. The concrete manifestations of these categories and their relations are not given but socially and historically produced. 


\section{REVIEW OF INTERNATIONAL POLITICAL ECONOMY}

Second, notwithstanding the challenges of American unilateralism, regionalism, and a lack of clear relationship between the WTO and competing multilateral organisations, the conceptual framework of transnational mercantilism provides a means to situate the current problems of the WTO within the broader perspective of a global trading order which must cope with two interrelated challenges: the comprehensiveness of commitments relating to a wide range of economic and social functions of the state, and the differentiation between market and non-market provisions. The argument has provided evidence of an ever-increasing scope of the WTO consistent with the transnationalising processes of capitalism that subsume new aspects of domestic policies which can have an impact on trade. In acknowledging the level of differentiation claimed by states on behalf of various and often opposing configurations of social forces, the paper suggests that the road towards transnationalisation is hindered by mercantilist practices, which differentiate the use value embodied by the exchanged goods. What is trade impacts not only on the fulfilment of a freer non-discriminatory trade, but also on the embeddedness of trade in state-society relations, in the natural environment and in the spatio-temporal structures of capitalism. The current concerns regarding the capacity of the WTO to fulfil the mandate agreed in Doha hinge on the impossibility of reaching a broad international understanding regarding the acceptable scope and priority to give these imperatives.

Finally, the significance of transnational mercantilism also reaches beyond the intergovernmental environment of the WTO and the public sphere of its engagement with global social movements. Whilst this paper has examined the shortcomings of the various attempts of the multilateral trading system to offer a credible response in terms of fair and sustainable trade, it does not address how the devolution of authority to non-state actors can be seen as another issue of major significance for the future of the multilateral trading system. When an average of two-thirds of world trade is related to intra-firm trade and extensive networks of inter-firm alliances are set up by various forms of cross-holdings, even the business-oriented The Economist can worry that 'private barriers to trade might replace those put up by the State'. ${ }^{16}$ In addition to the hierarchy of the market in intra-firm trade, private authority in international trade regulation also arises from the devolution of authority made possible by the WTO rules, in particular in health, safety and environmental matters. For instance, following the second triennial review of the Agreement on Technical Barriers to Trade, international voluntary standards set by hybrid bodies like the International Organisation for Standardisation (ISO) or private companies like the American Society for Testing and Materials (ASTM) can become authoritative sources for the purposes of the WTO mechanism in the settlement of disputes. This epitomises the shift in the balance between private and public authority as the regulatory scope of 
private actors expands. It clearly demonstrates, however, that the quest to rebuild a consensus around the WTO, as the core of the multilateral trading system, also rests on forces from both ends of the political spectrum and outside the intergovernmental environment. Both global social movements and private arrangements are transcending the framework of the WTO. Both have competing alternative agendas promoting more radical shifts in the global trading order.

\section{ACKNOWLEDGEMENTS}

This article draws on work conducted under the auspices of a Swiss National Science Foundation (FNS) Fellowship for Advanced Researchers, Public and Private Authority in Global Trade Governance. I am grateful to the FNS for its support and to the members of the Centre for Global Political Economy at the University of Sussex and the Centre d'Etudes et de Recherches Internationales (CERI) in Paris, as well as to three anonymous referees for their extremely helpful comments on earlier versions of this paper. I also would like to thank Liesl Graz for her invaluable help with the language.

\section{NOTES}

1 Works which discuss the new trade agenda include: Ostry $(1997,2000)$, Cable (1996), Feteketuky (1992), Sauvé and Zampetti (2000), Birdsall and Lawrence (1999). For one of the first study in this perspective, see Blackhurst (1981).

2 For historiographical reviews on mercantilism, see Magnusson (1994, 1993) and Perrotta (1988). The classics of the 1930s were Heckscher (1955) and Viner (1937). For the classics of the next generation of commentators, see Coleman (1969). For a massive collection of primary sources, see Magnusson (1995).

3 For various contributions to the heterodox tradition in global political economy, see for instance the following edited volumes: Higgott and Payne (2000); Palan (2000).

4 See note 2 above.

5 For analyses on the issue of legitimacy in the aftermath of Seattle, see Howse (2001), McGillivray (2000), Sampson (2001), Schott (2000), Wilkinson (2001).

6 See in particular Hugues and Wilkinson (2000); for background, see Charnovitz (1987).

7 For background, see SafeWork, Development of ILO Guidelines on Occupational Safety and Health Management Systems (OSH-MS). Information Note (Geneva: International Labour Organization, 2001), online: http:/ / www.ilo.org/public/english/protection/safework/managmnt/inote. htm 〈acceded 3 November 2001).

8 The decision to develop an International Standard providing guidelines for social responsibility was taken by Resolution 35/2004 of the Technical Management Board of the International Organization for Standardization, 24-25 June 2004. For further analysis, see Graz (2004).

9 The coverage of MFN for each GATS member is determined by a so-called negative list - it applies to all services except those listed in the Annex of 


\section{REVIEW OF INTERNATIONAL POLITICAL ECONOMY}

the agreement. The sectoral coverage of national treatment is determined by a positive list - it only applies to sectors listed in a member's schedule of commitments. For background on GATS, see Sauvé and Stern (2000).

10 The European draft requests lists to 28 other WTO member states were published on the following website: http://www.gatswatch.org/requestsoffers.html, 〈acceded 15 April 2003〉.

11 For the executive summary of the US requests, see: http://www.ustr.gov/ sectors/services/2002-07-01-proposal-execsumm.PDF 〈acceded 15 July 2002〉.

12 For the critique of the GATS, see, for instance, Barlow (2001) and the GATSWatch website: http://www.xs4all.nl/ ceo/gatswatch/. For the position of the Secretariat, see More (2001) and WTO (2001e).

13 The Guardian, May 18, 2002.

14 In the period 1980-1990, notifications on environmental grounds represented 7.8 percent of all notifications of technical barriers to trade; in 1998 the figure was 15 percent, 12.5 percent in 1999, and 15.6 percent in 2000 (WTO, 2001d).

15 See in particular The Capital, Book II, section 4, chap. XIII (Marx, 1968, 1104-5); see also Perrotta $(1988,126)$.

16 The Economist: A Survey of World Trade, October 3rd 1998, 14.

\section{REFERENCES}

Alvarez, J.E.E. (2002) 'Symposium: The Boundaries of the WTO', American Journal of International Law, 96(1): 1-158.

Bairoch, P. (2001) 'Les Leçons de l'Histoire', in M. Damian and J.-C. Graz (eds) Commerce International et Développement Soutenable, Paris: Economica.

Barlow, M. (2001) 'The Last Frontier', The Ecologist, 31(1): 38-42.

Ben-David, D., Noström, H. and Winters, L.A. (2000) Trade, Income Disparity and Poverty. Vol. 5, Special Studies, Geneva: World Trade Organization.

Bessière, M. (2001) 'A Knife at the Throat of Half a Billion Farmers', UNESCO Courier January.

Birdsall, N. and Lawrence, R.Z. (1999) 'Deep Integration and Trade Agreements: Good for Developing Countries?' in I. Kaul, I. Grunberg and M.A. Stern (eds) Global Public Goods, New York: Oxford University Press for the United Nations Development Program.

Blackhurst, R. (1981) 'The Twilight of Domestic Economic Policies', The World Economy, 4: 457-74.

Braudel, F. (1979) Civilisation Matérielle, Économie et Capitalisme, XV $V^{e}-X V I I I{ }^{e}$ Siècle. 3 vols, Paris: A. Colin.

Cable, V. (1996) 'The New Trade Agenda: Universal Rules Amid Cultural Diversity', International Affairs, 72(2): 227-46.

Charnovitz, S. (1987) 'The Influence of International Labor Standards on the World Trading Regime: An Overview', International Labour Review, 126: 56584 .

Coleman, D.C. (ed.) (1969) Revisions in Mercantilism, London: Methuen.

Cottier, T. (2002) 'Trade and Human Rights: A Relationship to Discover', Journal of International Economic Law, 5(1): 111-132.

Cox, R.W. with M. Schechter (2002), The Political Economy of a Plural World, London: Routledge.

Damian, M. and Graz, J.-C. (2001) 'The World Trade Organisation, the Environment, and the Ecological Critique', International Journal of Social Sciences, (170). 
Dymond, W.A. and Hart, M.M. (2000) 'Post-Modern Trade Policy. Reflections on the Challenges to Multilateral Trade Negotiations After Seattle', Journal of World Trade, 34(3): 21-38.

Feteketuky, G. (1992) The New Trade Agenda, Washington DC: Group of Thirty Occasional Paper No 40.

Gill, S. (2000) 'Toward a Postmodern Prince? The Battle in Seattle as a Moment in the New Politics of Globalisation', Millennium, 29(1): 131-40.

Graz, J.-C. (1999) Aux Sources de l'OMC: La Charte de La Havane, 1941-1950. Precursor to the WTO: The Stillborn Havana Charter, 1941-1950, Genève: Librairie Droz.

Graz, J.-C. (2004) 'Quand les normes font loi: topologie intégrée et processus différenciés de la normalisation internationale', Etudes Internationales, XXXV(2): 235-60.

Heckscher, E. (1955) Mercantilism. 2nd edition (1st edition engl. 1935). 2 vols, London: Allen \& Unwin.

Heilperin, M.A. (1963) Le Nationalisme Économique, Paris: Payot.

Higgott, R. and Payne, A. (eds) (2000) The New Political Economy of Globalisation. 2 vols, Aldershot: Edward Elgar.

Howse, R. (2001) 'The Legitimacy of the World Trade Organization', in J.-M. Coicaud and V. Heiskanen (eds) The Legitimacy of International Organizations, Tokyo: United Nations University Press.

Howse, R. (2002) 'From Politics to Technocracy', American Journal of International Law, 96(1): 94-117.

Howse, R. and Nicolaidis, K. (2001) 'Legitimacy and Global Governance: Why Constitutionalizing the WTO Is a Step Too Far', in R.B. Porter et al. (eds) Efficiency, Equity, and Legitimacy: The Multilateral Trading System at the Millennium.

Hugues, S. and Wilkinson, R. (2000) 'Labor Standards and Global Governance: Examining the Dimension of Institutional Engagement', Global Governance, 6: 259-77.

Jackson, J.H. (2000) The Jurisprudence of GATT and the WTO. Insights on Treaty Law and Economic Relations, Cambridge: Cambridge University Press.

Krueger, A.O. (ed.) (1998) The WTO as an International Organization, Chicago: Chicago University Press.

Kwa, A. (2002) Power Politics in the WTO, Bangkok: Focus on the Global South.

Lamy, P. (2001) ‘Global Policy without Democracy?' Conference on the Participation and Interface of Parliamentarians and Civil Societies for Global Policy, Berlin.

Magnusson, L. (1994) Mercantilism. The Shaping of an Economic Language, London and New York: Routledge.

Magnusson, L. (ed.) (1993) Mercantilist Economics, Boston, Dordrecht and London: Kluwer.

Magnusson, L. (ed.) (1995) Mercantilism. 4 vols, London and New York: Routledge.

Marceau, G. and Trachtman, J.P. (2002) 'The Technical Barriers to Trade Agreement, the Sanitary and Phytosanitary Measures Agreement, and the General Agreement on Tariffs and Trade. A Map of the World Trade Organization Law of Domestic Regulation of Goods', Journal of World Trade, 36(5): 811-81.

Margerum Harlen, C. (1999) 'A Reappraisal of Classical Economic Nationalism and Economic Liberalism', International Studies Quarterly, 43(4): 733-44.

Marx, K. (1968) Oeuvres. Économie II, Paris: Gallimard, Bibliothèque de la Pléiade.

May, C. (1998) 'Thinking, Buying, Selling: Intellectual Property Rights in Political Economy', New Political Economy, 3(1): 59-78.

Mazoyer, M. and Roudart, L. (2002) Histoire des Agricultures du Monde. Du Néolithique à la Crise Contemporaine, Paris: Seuil.

McGillivray, F. (2000) Democratizing the World Trade Organization, Standford: Hoover Institution on War, Revolution and Peace. 


\section{REVIEW OF INTERNATIONAL POLITICAL ECONOMY}

Menotti, V. (2002) 'From Doha to Johannesburg: Who Will Decide Our Common Future?' Bridges, 6(3): 1-2.

More, M. (2001) 'Liberalization? Do Not Reject It Just Yet', The Guardian 26 February. Morini-Comby, J. (1930) Mercantilisme et Protectionnisme. Essai sur les Doctrines Interventionnistes en Politique Commerciale du XVe au XIXe Siècle, Paris: Alcan.

Ostry, S. (1997) The Post-Cold War Trading System. Who's on First? Chicago: Chicago University Press.

Ostry, S. (2000) 'Looking Back to Look Foward: The Multilateral Trading System after 50 years', in WTO Secretariat (ed.) From GATT to the WTO: The Multilateral Trading System in the New Millennium, The Hague, London and Boston: Kluwer Law International.

OXFAM (2002) Rigged Rules and Double Standards. Trade, Globalisation and the Fight Against Poverty, London: online www.marketradefair.com.

Palan, R. (1998) 'Les fantômes du capitalisme mondial: l'économie politique internationale et l'école française de la régulation', L'Année de la régulation, 2: 63-86.

Palan, R. (ed.) (2000) Global Political Economy. Contemporary Theories, London and New York: Routledge.

Perrotta, C. (1988) Produzione e Lavoro Produttivo nel Mercantilismo e nell'Illuminism, Galatina: Congedo Editore.

Perrotta, C. (1991) 'Is the Mercantilist Theory of the Favorable Balance of Trade Really Erroneous?' History of Political Economy, 23(2): 301-336.

Perrotta, C. (1997) 'The Preclassical Theory of Development : Increased Consumption Raises Productivity', History of Political Economy, 29(2): 295-326.

Petersmann, E.-U. (1991) Constitutional Functions and Constitutional Problems in International Economic Law, Boulder: Westview Press.

Petersmann, E.-U. (2003) 'Human Rights and the Law of the World Trade Organization', Journal of World Trade, 37(2): 241-81.

Picciotto, S. (2003) 'Private rights vs public standards in the WTO', Review of International Political Economy, 10(3): 377-405.

Piot, P. (2003) Speech by the Executive Director of the Joint United Nations Programme on HIV/AIDS to the 59th Session of the United Nations Commission on Human Rights, Geneva, 19 March.

Ramonet, I. (2003) 'Viva Brasil!', Le Monde Diplomatique, Janvier.

Rupert, M. (1995) Producing Hegemony. The Politics of Mass Production and American Global Power, Cambridge: Cambridge University Press.

Sampson, G.P. (ed.) (2001) The Role of the World Trade Organization in Global Governance, Tokyo: United Nations University Press.

Sauvé, P. and Stern, R.M. (eds) (2000) GATS 2000. New Directions in Services Trade Liberalisation, Washington DC: Brookings Institution.

Sauvé, P. and Zampetti, A.B. (2000) 'Subsidiarity Perspectives on the New Trade Agenda', Journal of International Economic Law, 3(1): 83-114.

Schott, J. (2000) The WTO after Seattle, Washington DC: Institute for International Economics.

Sell, S. (1999) 'Multinational Corporations as Agents of Change: The Globalization of Intellectual Property', in C. Cutler, V. Haufler, P. Porter (eds) Private Authority in International Affairs, Albany, SUNY Press.

Siroën, J.-M. (1992) 'Le Nationalisme dans les Relations Économiques Internationales', Revue Française d'Économie VII(1): 3-33.

Stephens, C. (ed) (2003) 'Special and Differential Treatment in Terms of Trade', IDS Bulletin, 34(2) April. Special Issue.

Trebilcock, M.J. and Howse, R. (1999) The Regulation of International Trade. 2nd edition, London: Routledge. 


\section{GRAZ: TRANSNATIONAL MERCANTILISM}

UNCTAD (1999a) The World Commodity Economy: Recent Evolution, Financial Crises, and Changing Market Structures, Report to the Commission on Trade in Goods and Services and Commodities, Geneva: UNCTAD.

UNCTAD (1999b) Trade and Development Report, New York and Geneva: United Nations.

Viner, J. (1937) Studies in the Theory of International Trade, London: Allen \& Unwin.

Wall Street Journal (2001) 'Drug Makers' Fight For Patent Rights Puts Them in a Vise', 5 March

Wilkinson, R. (2000) Multilateralism and the World Trade Organisation. The Architecture and Extension of International Trade Regulation, London and New York: Routledge.

Wilkinson, R. (2001) 'The WTO in Crisis: Exploring the Dimensions of Institutional Inertia', Journal of World Trade, 35(3): 397-419.

World Trade Organization. (1999) Communication from the United States to the Council for Trade and Services, Geneva, 5 August, WT/GC/W/295; S/C/W/ 119.

World Trade Organization. (2000) Note on non-trade concerns. Submission to the Special Session of the WTO Committee on Agriculture by Barbados, Burundi, Cyprus, Czech Republic, Dominica, Estonia, the European Communities, Fiji, Iceland, Israel, Japan, Korea, Latvia, Liechtenstein, Madagascar, Malta, Mauritania, Mauritius, Mongolia, Norway, Poland, Romania, Saint Lucia, Slovak Republic, Slovenia, Switzerland, and Trinidad and Tobago, Geneva, 9 November, G/AG/NG/W/36/Rev.1.

World Trade Organization. (2001a) Ministerial Declaration, Doha, 14 November, $\mathrm{WT} / \mathrm{MIN}(01) / \mathrm{DEC} / 1$.

World Trade Organization. (2001b) Declaration on the TRIPs Agreement and Public Health. Ministerial Conference, Fourth Session, Doha, 14 November, $\mathrm{WT} / \mathrm{MIN}(01) / \mathrm{DEC} / \mathrm{W} / 2$.

World Trade Organization. (2001c) Implementation-Related Issues and Concerns, Ministerial Conference, Fourth Session, Doha, 14 November, WT/MIN(01)/17.

World Trade Organization. (2001d) Environmental Database for 2000. Note by the Secretariat of the Committee on Trade and Environment, Geneva, 20 June, $\mathrm{WT} / \mathrm{CTE} / \mathrm{W} / 195$.

World Trade Organization. (2001e) GATS - Facts and Fiction, Geneva: World Trade Organization. 